\title{
ACUTE CONTACT TOXICITY OF SIX PESTICIDES IN HONEYBEES (APIS MELLIFERA MEDA) IN IRAN
}

\author{
Farhang Rasuli ${ }^{1}$ \\ Javad Nazemi Rafie ${ }^{1 *}$ \\ Amin Sadeghi \\ ${ }^{1}$ University of Kurdistan, Iran \\ ${ }^{2}$ University of Kurdistan, Faculty of Agriculture, Departament of Plant Protection \\ *corresponding author: j.nazemi@uok.ac.ir \\ Received: 06 August 2015; accepted: 15 March 2017
}

A B S T R A C T

Pollination has an important role in both agricultural production and wild plant reproduction. For the pollination of crops, agriculture relies largely on managed colonies of the honeybee Apis mellifera. Worker bees are primarily affected by pesticides. The symptoms of poisoning vary depending on the developmental stage of the individual bee and kind of chemical employed. The acute contact toxicity of insecticides (phosalone and pirimicarb), acaricide (propargite), insecticide and acaricide (fenpropathrin), fungicides and bactericides (copper oxychloride and bordeaux mixture) was assessed in Iran through laboratory experiments. The median lethal concentrations $\left(\mathrm{LC}_{50}-24 \mathrm{~h}, \mathrm{LC}_{50}-48 \mathrm{~h}\right.$ and $\mathrm{LC}_{50}-72 \mathrm{~h}$ ) were evaluated for the purposes of this research. Results showed that fenpropathrin had high toxicity; $\mathrm{LC}_{50}-24 \mathrm{~h}, \mathrm{LC}_{50}-48 \mathrm{~h}$ and $\mathrm{LC}_{50}-72 \mathrm{~h}$ were $5.7,3.2$ and $2.9 \mathrm{ppm}$ respectively. Additionally, the bordeaux mixture had the minimum contact toxicity on honeybees with $L C_{50}-24 h, L C_{50}-48 h$ and $L C_{50}-72 h$ being 79,$926 ; 69,552$ and 69,045 ppm respectively and was safe and non-toxic in honeybees.

Keywords: Apis mellifera meda, Contact Toxicity, $\mathrm{LC}_{50}$, Pesticide

\section{INTRODUCTION}

Crop pollination relies largely on managed colonies of Apis mellifera (Gallai et al., 2009). Unfortunately, recently all over the worldcolonies have disappeared, better known as "Colony Collapse Disorder" (CCD) (Mullin et al., 2010). Factors such as parasites and pesticides or a combination of these factors might be responsible for a decline in the health of honeybees (VanEngelsdorp et al., 2009). To date, contact toxicity of some pesticides has been tested on honeybees, and those such as synthetic organophosphate, carbamate and pyrethroid insecticides have a significant impact on bees and pollination.

Honeybees are estimated to provide the agriculture industry annual pollination services worth US \$4.1 billion. Each year, dozens of beekeepers with hundreds of bee colonies move to various hills and valleys of Himachal Pradesh and apple farmers pay them IRs 800 (US \$18) for one colony of honeybees to provide pollination services during each flowering season (Hepburn \& Radloff, 2011).

Pesticides are important for ensuring both crop quality and quantity in sustainable agricultural production. The use of pesticides is one of the most effective practices in controlling pests (Kevan, 1999). In the assessment and evaluation of toxic characteristics of substances, the acute toxicity in honeybees needs to be determined. The acute toxicity test is conducted to determine the inherent toxicity of pesticides and other chemicals to honeybees. In particular, this method can be used in stepwise programs for evaluating the hazards of pesticides to bees, based on sequential progression from laboratory toxicity tests to semi-field and field experiments (OECD, 1998; OEPP/EPPO, 1993). Therefore, active substances and formulated pesticides currently undergo various tests for the assessment of their risk to honey bees, before they are allowed to be used in agriculture. For this study, the European and Mediterranean Plant Protection Organization guidelines 


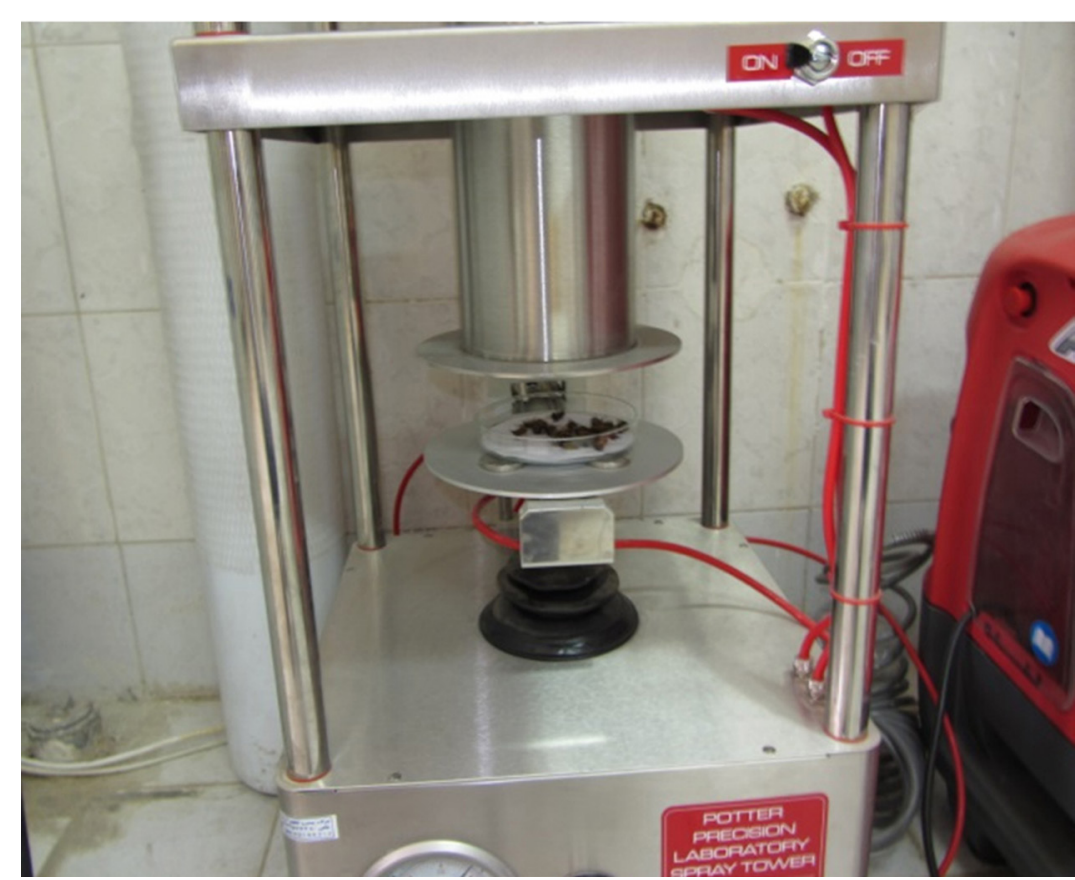

Fig. 1 Spray tower for contact toxicity experiments

No. 170 (OEPP/EPPO, 2010a) and the relative risk assessment scheme (OEPP/EPPO, 2010b) were followed.

Insecticides are normally designed to control insect pests but they can also affect non-target organisms, including the honeybee an insect of agro-environmental, economic and scientific importance (Gallai et al., 2009; Gauthier, 2010; Srinivasan, 2011). The EFSA Guidance Document suggests a tiered risk assessment scheme with a simple and cost-effective first tier to more complex higher tier studies under field conditions. Each of the tiers will have to ensure that the appropriate level of protection is achieved (EFSA, 2013).

Since there is no published information on the precise acute toxicity $\left(\mathrm{LC}_{50}\right)$ of phosalone, pirimicarb, propargite, fenpropathrin, copper oxychloride and bordeaux mixture to Apis mellifera meda, $\mathrm{LC}_{50}-24 \mathrm{~h}, \mathrm{LC}_{50}-48 \mathrm{~h}$ and $\mathrm{LC} 50-72 \mathrm{~h}$ were evaluated to fill this gap in the data. The aim of this study was to calculate $\mathrm{LC}_{50}-24 \mathrm{~h}, \mathrm{LC}_{50}-48 \mathrm{~h}$ and $\mathrm{LC} 50-72 \mathrm{~h}$ of six pesticides.

\section{MATERIAL AND METHODS}

Commercial formulations available in Iran were used. These formulations contained Phosalone (Zolone ${ }^{\oplus}$ 35.0\% EC), Pirimicarb (Pirimor ${ }^{\circledR}$, 50\%
WP), Propargite (Omite ${ }^{\oplus}$, D-014", BPPS $^{\oplus}$, Comite ${ }^{\oplus}, 57 \%$ EC), Fenpropathrin (Danitol ${ }^{\circ}, 10 \% \quad E C$ ), Copper oxychloride (Cupravit, 355\%, $35 \%$ WP) and Bordeaux mixture (Bordeaux Fix ${ }^{\oplus}, 18 \%$ EC). Bioassay experiments were conducted in 2015. Worker honeybees were used for contact toxicity, honeybee foragers were obtained from one adequately fed, healthy, diseasefree and queen-right colony, and forager honeybees were sampled from one colony.

Pretest experiments were conducted then six concentrations were prepared for each pesticide. Honeybees were anaesthetized with $\mathrm{CO} 2$ gas, and fifteen worker honey bees were transferred to each petri dish. Three petri dishes were used as replications for each concentration. $2 \mathrm{ml}$ volume of each treatment was sprayed on the dorsal surface of honeybees with a spray tower (with two bar pressure) (Fig. 1). 270 worker honeybees (four to six weeks age) were used for each pesticide and 45 workers for each control. After treatment, three cages $(30 \mathrm{~cm}$ high and $20 \mathrm{~cm}$ wide) were used in each concentration and one cage for control. The fifteen worker honeybees of each replication were laid in each cage and fed with pure sucrose solution in water $(50 \% \mathrm{w} / \mathrm{v})$. Mesh-like nets in parts of the cages provided ventilation. A sleeve - like net was applied to transfer the treated petri dish into the cage.

The mortality rates were logged at 24, 48 and $72 \mathrm{~h}$ after the start of the test. The tests were performed in a dark room at $25-30^{\circ} \mathrm{C}$ and 45-55\% relative humidity (Laurino et al., 2010; 2011; 2013). Experiments lasted until the time (day) that control mortality did not exceed 10 percent ( $\leq 10 \%$ ) (OECD 1998; Laurino et al., 2013). In our experiment, control mortality exceeded 10 percent after 72 hours ( $210 \%)$, so we did not continue observation records to 96 hours. $L C_{50}-24 h, L C_{50}-48 h L_{50}-72 h$ were calculated using Polo-PC software. Probit regressions were plotted by SPSS ver. 18. A sig- 
Table 1.

Comparisons of $L_{10^{\prime}} L_{50}$ and $L C_{90}$ of commonly used pesticides in Iran

\begin{tabular}{|c|c|c|c|c|c|c|c|c|c|c|c|c|c|c|c|}
\hline \multirow{2}{*}{ 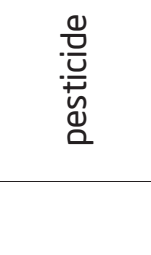 } & \multicolumn{3}{|c|}{$\mathrm{LC}_{50}(\mathrm{ppm})$} & \multicolumn{3}{|c|}{ Slop $\pm S E$} & \multicolumn{3}{|c|}{ Chi-square } & \multicolumn{3}{|c|}{$\mathrm{LC}_{10}(\mathrm{ppm})$} & \multicolumn{3}{|c|}{$\mathrm{LC}_{90}(\mathrm{ppm})$} \\
\hline & $24 \mathrm{~h}$ & $48 \mathrm{~h}$ & $72 \mathrm{~h}$ & $24 \mathrm{~h}$ & $48 \mathrm{~h}$ & $72 \mathrm{~h}$ & $24 \mathrm{~h}$ & $48 \mathrm{~h}$ & $72 \mathrm{~h}$ & $24 \mathrm{~h}$ & $48 \mathrm{~h}$ & $72 \mathrm{~h}$ & $24 \mathrm{~h}$ & $48 \mathrm{~h}$ & $72 \mathrm{~h}$ \\
\hline $\begin{array}{l}\stackrel{0}{\check{L}} \\
\frac{0}{\tilde{N}} \\
\stackrel{\text { Oे }}{\frac{1}{\alpha}}\end{array}$ & 965.5 & 773.7 & 762.8 & $\begin{array}{l}12.5 \\
\pm 2.5\end{array}$ & $\begin{array}{r}8.6 \\
\pm 1.2\end{array}$ & $\begin{array}{r}9.4 \\
\pm 1.5\end{array}$ & 2.98 & 2.1 & 5.7 & 763.1 & 550.9 & 557.3 & 1221.4 & 1086.6 & 1044.1 \\
\hline 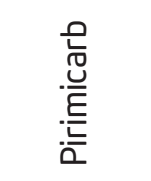 & 790.28 & 705.6 & 701.9 & $\begin{array}{r}15.1 \\
\pm 2.5\end{array}$ & $\begin{array}{r}11.6 \\
\pm 2.1\end{array}$ & $13.5 \pm 2$ & 0.97 & 2.5 & 5.3 & 650.5 & 547.9 & 564.4 & 960.06 & 908.6 & 873.1 \\
\hline 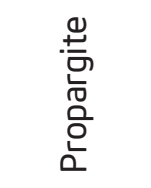 & 31283 & 26659 & 25049 & $\begin{array}{l}13.5 \\
\pm 1.6\end{array}$ & $\begin{array}{c}11 \\
\pm 1.3\end{array}$ & $12.2 \pm 1.3$ & 2.7 & 2.4 & 6.9 & 25159 & 20427 & 19699 & 38898 & 34793 & 31852 \\
\hline 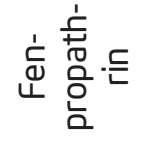 & 5.7 & 3.2 & 2.9 & $\begin{array}{c}5.1 \\
\pm 0.6\end{array}$ & $\begin{array}{c}2.6 \\
\pm 0.34\end{array}$ & $\begin{array}{c}3.1 \\
\pm 0.3\end{array}$ & 1.4 & 1.9 & 7.7 & 3.18 & 1.03 & 1.1 & 10.06 & 9.76 & 7.4 \\
\hline 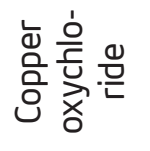 & 29396 & 24444 & 23819 & $\begin{array}{c}8.7 \\
\pm 1.2\end{array}$ & $\begin{array}{c}7.8 \\
\pm 1.1\end{array}$ & $\begin{array}{r}8.8 \\
\pm 1.1\end{array}$ & 1.6 & 1.7 & 3.6 & 20982 & 16783 & 17091 & 41184 & 35601 & 33196 \\
\hline 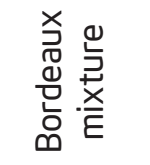 & 79926 & 69552 & 69045 & $\begin{array}{l}12.1 \\
\pm 1.7\end{array}$ & $\begin{array}{r}9.9 \\
\pm 1.4\end{array}$ & $11.7 \pm 1.6$ & 2.1 & 2.3 & 5.01 & 62718 & 51749 & 53665 & 101860 & 93479 & 88832 \\
\hline
\end{tabular}

nificant comparison between $\mathrm{LC}_{50}-24 \mathrm{~h}$ and $\mathrm{LC}_{50}-48 \mathrm{~h}$ was conducted by lethal dose ratio method (Robertson \& Preisler, 1992). Concentrations used to determine the $\mathrm{LC}_{50}$ were Copper oxychloride- 16,000; 20,000; 25,000; 30,000; 35,000 and 40,000 ppm (active ingredient); Phosalone- 500, 700, 900, 1000, 1100 and 1250 ppm (active ingredient); Primicarb- 400, 600, 700, 800, 900 and 1100ppm (active ingredient); Propargite- 20,000; 25,000; 28,000; 32,000; 35,000 and 38,000 ppm (active ingredient); Fenpropathrin- 1, 3, 5, 7, 9 and 10 ppm (active ingredient); Bordeaux mixture- 50,000; 60,000; 70,000; 80,000; 90,000 and 100,000 ppm (active ingredient);

\section{RESULTS:}

Results showed that fenpropathrin had the highest toxicity compared to the other pesticides $\left(\mathrm{LC}_{50}-24 \mathrm{~h}=5.7 \mathrm{ppm}\right)$ meaning it must be not applied during the flowering time of crops and trees. Even, $0.01 \mathrm{ml} / \mathrm{L}(10 \mathrm{ppm})$ of fenpropathrin could have caused $90 \%$ mortality within $24 \mathrm{~h}$ after the experiment. Also, $\mathrm{LC}_{50}$ of fenpropathrin decreased from $24 \mathrm{~h}$ to $72 \mathrm{~h}$ after experiment, and there was significant difference between $L C_{50}$ at $24 \mathrm{~h}$ and $L C_{50}$ at $48 \mathrm{~h}$ (lethal dose ratio=0.4-0.6) (Tab. 1\&2). Results indicated that regression slops between the log of concentration and mortality probit decreased from $24 \mathrm{~h}$ to $48 \mathrm{~h}$ in all studied pesticides (Tab. 1 \& Fig. 3). The 

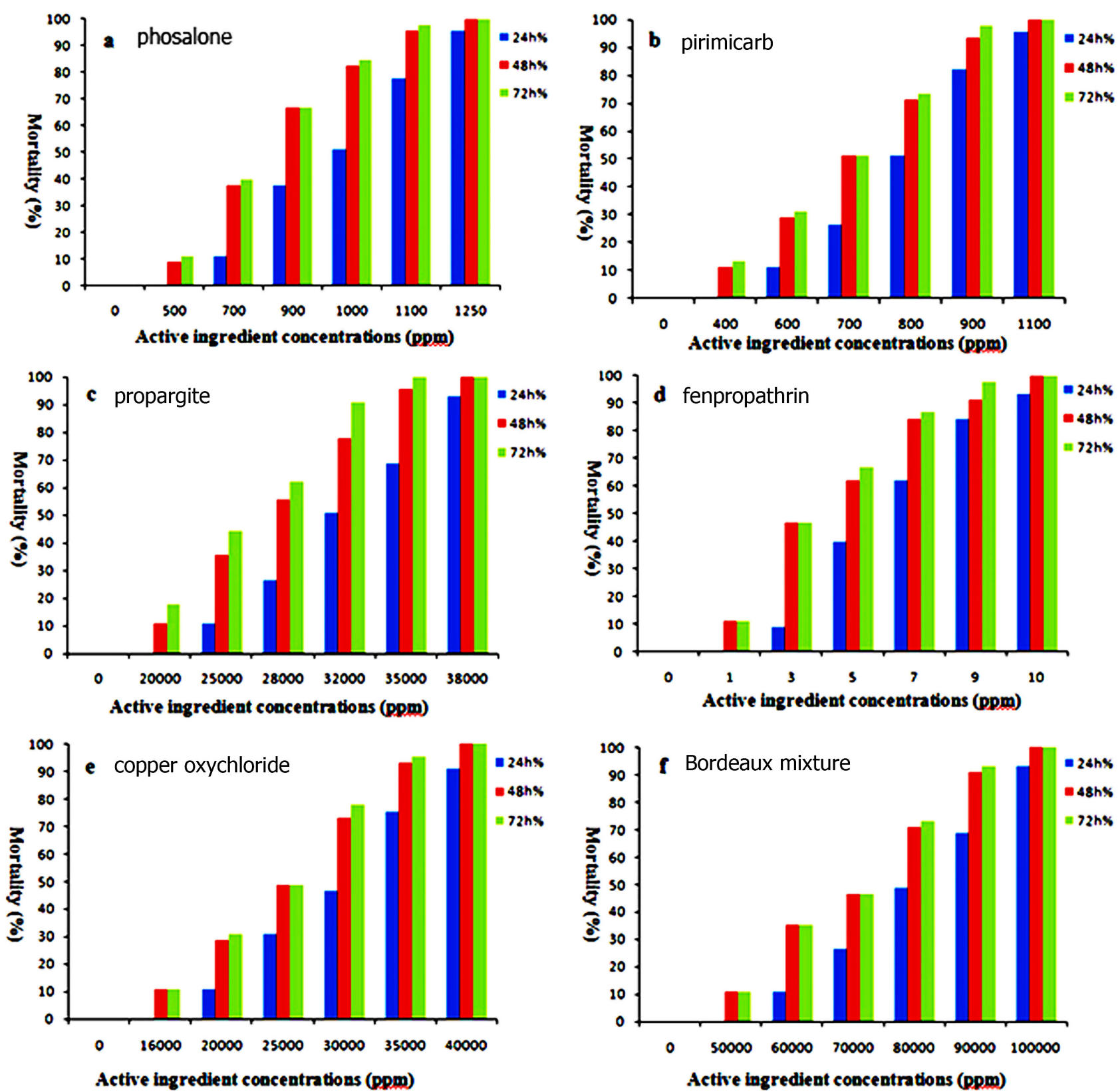

Fig. 2 Mortality comparisons of worker honeybees in different concentrations (active ingredient) at 24h, 48h and 72h. a- phosalone, b- pirimicarb, c- propargite, d- fenpropathrin, e- copper oxychloride, f-Bordeaux mixture

bordeaux mixture and copper oxychloride had high LC $_{50}-24$ which proved they were non-toxic for foraging honeybees. The application of almost $31.2 \mathrm{ml} / \mathrm{L}$ propargite (acaricide) caused $50 \%$ mortality in $24 \mathrm{~h}$ after the experiment demonstrating it was safe for common usage in flowering time (Tab. 2). Additionally, LC $_{50}$ decreased from $24 \mathrm{~h}$ to $72 \mathrm{~h}$ after the experiment in all pesticides. $\mathrm{LC}_{90}$ decreased from $24 \mathrm{~h}$ to $72 \mathrm{~h}$ after experiment in all pesticides while $\mathrm{LC}_{10}$ decreased from $24 \mathrm{~h}$ to $72 \mathrm{~h}$ only in fenpropathrin and propargite (Tab.1). LC $_{50}$ comparisons indicated that there was significant difference between $\mathrm{LC}_{50}-24 \mathrm{~h}$ and $\mathrm{LC}_{50}-48 \mathrm{~h}$ in all pesticides but not between $\mathrm{LC}_{50}-48 \mathrm{~h}$ and $\mathrm{LC}_{50}-72 \mathrm{~h}$. We found only a significant parallelism between $\mathrm{LC}_{50}-24$ and $\mathrm{LC}_{50}-48$ in fenpropathrin. Our results showed that pirimicarb as a specific toxic to aphids was moderately safe to honeybees meaning it could be used safely with foraging pollinator bees. Also, phosalone was moderately toxic so it should be not used during flowering (Tab. 2). There was a significant difference between the mortalities of applied concentra- 
Table 2.

Significant evaluation and parallelism hypothesis between $\mathrm{LC}_{50}-24$ hours, $\mathrm{LC}_{50}-48$ hours and 72 hours of pesticides

\begin{tabular}{ccccccccc}
\hline pesticides & & LC & & \multicolumn{2}{c}{ Parallelism (Chi-square) } & df & \multicolumn{2}{c}{$\begin{array}{c}\text { Lethal Dose Ratio } \\
\text { (lower-upper limits) }\end{array}$} \\
\hline & $\begin{array}{c}24 \\
\text { hours }\end{array}$ & $\begin{array}{c}48 \\
\text { hours }\end{array}$ & $\begin{array}{c}72 \\
\text { hours }\end{array}$ & $\begin{array}{c}24 \text { hours with } \\
\text { 48 hours }\end{array}$ & $\begin{array}{c}72 \text { hours with } \\
48 \text { hours }\end{array}$ & $\begin{array}{c}24 \text { hours with } \\
48 \text { hours }\end{array}$ & $\begin{array}{c}72 \text { hours } \\
\text { with } 48 \\
\text { hours }\end{array}$ \\
\hline Phosalone & 965.5 & 773.7 & 762.8 & $1.64(P=0.2)^{\star}$ & $0(P=0.95)$ & 1 & $0.7-0.8^{\star *}$ & $0.9-1.1$ \\
Pirimicarb & 790.28 & 705.6 & 701.9 & $0.49(P=0.4)$ & $0.03(P=0.85)$ & 1 & $0.8-0.9$ & $0.9-1.07$ \\
Propargite & 31283 & 26659 & 25049 & $0.92(P=0.33)$ & $0.04(P=0.84)$ & 1 & $0.80-0.89$ & $1-1.12$ \\
Fenpropathrin & 5.7 & 3.2 & 2.9 & $9.49(P=0.002)$ & $0.35(P=0.55)$ & 1 & $0.4-0.6$ & $0.8-1.3$ \\
Copper oxychloride & 29396 & 24444 & 23819 & $1.03(P=0.33)$ & $0.05(P=0.82)$ & 1 & $0.7-0.9$ & $0.9-1.1$ \\
Bordeaux mixture & 79926 & 69552 & 69045 & $1.4(P=0.23)$ & $0.06(P=0.8)$ & 1 & $0.8-0.9$ & $0.9-1.08$ \\
\hline
\end{tabular}

* Parallelism hypothesis is not rejected in $\mathrm{P}>0.05$

** If $95 \%$ confidence interval includes 1 , then $L D_{50}-24 \mathrm{~h}$ and $L D_{50}-48 \mathrm{~h}$ are not significantly different.

*** Lethal dose ratio is a method for statistical comparisons of $\mathrm{LC}_{50}$

tions of propargite at $24 \mathrm{~h}$ after the experiment $(F=120.7, P=0.00)$ as well as between those of applied concentrations of copper oxychloride at 24h ( $F=106.7, P=0.00)$. Results demonstrated that concentrations of 10; 1100; 1250; 38,000; 40,000 and 100,000 ppm caused $100 \%$ mortalities at $48 \mathrm{~h}$ and $72 \mathrm{~h}$ in fenpropathrin, pirimicarb, phosalone, propargite, copper oxychloride and bordeaux mixture respectively (Fig. 2).

\section{DISCUSSION}

Despite the efforts of many researchers, the question of the possible causes of CCD has not yet been fully resolved, but one of the important causes is believed to be the indiscriminate use of insecticides in agricultural practice. This investigation is focused on only one aspect of the effect of these substances on the insect's body thatcould provide a solution to the current threat to Apis mellifera. On the other hand, the individual honeybees s have weakly developed immune and detoxifying systems because the amount of monooxygenase coding genes P450 or glutation-S-transferase of this species is nearly $50 \%$ lower than in other representatives of the insects (Piechowicz et al., 2013).

Our results showed that phosalone, pirimicarb (insecticides) and fenpropathrin (insecticide and acaricide) were more toxic than fungicides and bactericides because copper oxychloride and bordeaux mixture have different mode of action than insectides. Copper oxychloride and bordeaux mixture seem to be more toxic through oral exposure $\left(\mathrm{LC}_{50}=5,408 \mathrm{ppm}\right.$ and 4,469 ppm respectively, Rasuli et al., 2015) than through contact probably because they can penetrate more easily via the midgut than via the external cuticular layer.

Fenpropathrin was the most toxic toApis mellifera workers $\left(\mathrm{LC}_{50} 24 \mathrm{~h}=5.7 \mathrm{ppm}\right)$ in comparison to phosalone and pirimicarb. The chemical family of fenpropathrin аге ругеthroids and has different mode of action than carbamates (pirimicarb)and organophosphates (phosalone). These inhibit the enzyme acetylcholinesterase which serves to interrupt the transmission of nerve impulses whereas fenpropathrin acts as an axonic poison by interfering with the sodium channels of both the peripheral and central nervous system thereby stimulating repetitive nervous discharges and leading to paralysis.

Furthermore, results showed that propargite (acaricide) with $\mathrm{LC}_{50}-24 \mathrm{~h}=31,283 \mathrm{ppm}$ was non-toxic for honeybees because its mode of 


\section{_ BhSULl ET HL. _ Acute Contact Toxicity of Pesticides in Honeybee}


Fig 3. Probit regression lines of commonly used pesticides in 24 hours, 48 hours and 72 hours; a- phosalone, b-pirimicarb, c-propargite, d-fenpropathrin, e- copper oxychloride, f- bordeaux mixture 
action (inhibitors of mitochondrial ATP) differed from other insecticides. Our research showed that $\mathrm{LC}_{50}-24 \mathrm{~h}$ and $\mathrm{LC}_{50}-48 \mathrm{~h}$ of phosalone was 966 and 774 ppm, respectively. Additionally, LC $_{90}-24 \mathrm{~h}$ was $1221 \mathrm{ppm}$. The usage instruction of the trade formulation of phosalone $35 \%$ is 1500 ppm for controlling pests, so this insecticide is moderately toxic to honeybees. There is only fragmented data regarding moderate toxicity of phosalone in honeybees (Mayer et al., 1999; Sanford, 2009; Adams \& Bartholomew, 2012).

There is not any precise information concerning acute contact toxicity in fungicides and bactericides of copper oxychloride and Bordeaux mixture. Our research showed that the $\mathrm{LC}_{50}-24 \mathrm{~h}$ of copper oxychloride and Bordeaux mixture were 29.396 and 79.926 ppm of the active ingredient, respectively. The usage instruction of trade formulation of copper oxychloride $35 \%$ and bordeaux mixture $18 \%$ were 2000 to 5000 ppm in Iran, hence these pesticides were non-toxic to honeybees. Tesoriero et al., (2003) showed that $1 \mu$ copper oxychloride did not have a toxic effect on adult Osmia cornuta (Latreille) but at $1 \mu$ per egg caused $40 \%$ mortality in eggs. Individual studies of fungicides showed that they had little effect on honeybees. However Vandame \& Belzunces (1998) examined the combined effect of a fungicide and the insecticide deltamethrin and found a significant effect on honeybee thermoregulation. Our results showed that pirimicarb was safe for Apis mellifera and because of its specific toxicity to aphids it could be used safely with pollinator bees.

Risk assessments of the six pesticides showed that Fenpropathrin (acaricide and insecticide) was highly toxic in honeybees and must not be used during the foraging of honeybees. Furthermore, propargite (acaricide), Copper oxychloride and Bordeaux mixture (fungicides and bactericides) were non-toxic for honeybees therefore could be used safely during the foraging of honeybees (Apis mellifera). Additionally, Pirimicarb was particularly toxic to aphids and could be used safely with pollinator bees.

\section{ACKNOWLEDGMENTS}

The authors would like to thank the Plant Protection Department, Faculty of Agriculture, University of Kurdistan, Iran, for their financial assistance.

\section{REFERENCES}

Adams, R.G., \& Bartholomew, C. (2012). Protecting honey bees from pesticide poisoning. University of connecticut, 7 pp.

EFSA. (European Food Safety Authority). (2013). EFSA Guidance Document on the risk assessment of plant protection products on bees (Apis mellifera, Bombus spp. and solitary bees). EFSA Journal, 77(7), 268pp.

EPPO/Council of Europe. (1993). Decision-Making Scheme for the Environmental Risk Assessment of Plant Protection Products - Honeybees. EPPO bulletin, 23(1), 151-165.

Gallai, N., Salles, J.M., Settele, J., \& Vaissière, B.E. (2009). Economic valuation of the vulnerability of world agriculture confronted with pollinator decline. Journal of Ecological Economics, 68(3), 810-821.

Gauthier, M., Dacher M., Thany, S.H., Niggebrugge, C., Deglise, P., Kljucevic, P., Armengaud, C., Grünewald, B. (2010). Involvement of alpha-bungarotoxin-sensitive nicotinic receptors in long-term memory formation in the honeybee (Apis mellifera). Neurobiology of Learning and Memory, 86(1), 164-174.

Hepburn, R., \& Radloff, S. (2011). Honeybees of Asia. Springer-Verlag Berlin Heidelberg.

Kevan, P. G. (1999). Pollinators as bioindicators of the state of the environment: species, activity and diversity. Agriculture Ecosystems and Environment, 74,373-393.

Laurino, D., Manino, A., Patetta, A., Ansaldi, M., Porporato, M. (2010). Acute oral toxicity of neonicotinoids on different bee strains. Redia, 93, 99-102. 
Laurino, D., Manino, A., Patetta, A., Ansaldi, M., Porporato, M. (2011), Toxicity of neonicotinoid insecticides to honey bees: laboratory tests. Bulletin of Insecto/ogy, 64, 107-113.

Laurino, D., Manino, A., Patetta, A., Ansaldi, M., Porporato, M. (2013). Toxicity of neonicotinoid insecticides on different honey bee genotypes. Bulletin of Insectology, 66(1), 119-126.

Mayer, D.F., Johansen, C.A., \& Baird, C.R. (1999). How to reduce bee poisoning from pesticides. Pacific Northwest Extension Publication PNW 518.

Mullin, C.A., Frazier, M., Frazier, J.L., Ashcraft, S., Simonds, R., van Engelsdorp, D., Pettis, J.S. (2010). High levels of miticides and agrochemicals in North American apiaries. implications for honey bee health. PLoS ONE 5:3 pp. 9754.

OECD. (1998). Gaudiness for the testing of chemical No. 213. Honeybees, Acute Oral Toxicity Test. Section 2. effect on biotic systems. OECD, Paris, DOl: 10.178719789264070165-en.

OEPP/EPPO. (2010a). EPPO Standards PP1/170 (4). Efficacy evaluation of plant protection products, Side-effects on honeybees. OEPP/EPPO Bulletin, 40,313-319.

OEPP/EPPO. (2010b). EPPO Standards PP3/10 (3). Environmental risk assessment for plant protection products. Chapter 10: honeybees. OEPP/EPPO Bulletin, 40, 323-331.

Piechowicz, B., Grodzicki, P., Stawarczyk, M., Stawarczyk, K. (2013). Circadian and seasonal changes in honeybee (Apis mellifera) worker susceptibility to diazinon, teflubenzuron, pirimicarb, and indoxacarb. The Polish Journal of Environmental Studies, 22(5), 1457-1463.

Rasuli, F., Nazemi Rafie, J., \& Sadeghi, A. (2015). The acute oral toxicity of commonly used pesticides in Iran, to honeybees (Apis mellifera meda). Journal of Apicultural Science, 59(1), 17-26. DOl 10.1515/jas2015-0007
Robertson, J. L., \& Preisler, H. K. (1992). Pesticide Bioassays with Arthropods. CRC Press Boca Raton, FL, USA.

Sanford, M.T. (2009). Protecting honey bees from pesticides. University of Florida 13 pp.

Srinivasan, M. V. (2011). Honeybees as a Model for the Study of Visually Guided Flight, Navigation, and Biologically Inspired Robotics. Physiological Reviews, 97, 413-460.

Tesoriero, D., Maccagnani, B., Santi, F., \& Celli, G. (2003). Toxicity of three pesticides on larval instars of Osmia cornuta: preliminary results. Bulletin of Insectology, 56(1), 169-171.

Vandame, R., \& Belzunces, L.P. (1998). Joint actions of deltamethrin and azole fungicides on honey bee thermoregulation. Neuroscience Letters, 25(1), 5760.

VanEngelsdorp, D., Hayes, J., Underwood, R., \& Pettis, J. (2009). A survey of honey bee colony losses in the United States, fall 2008 to spring 2009. Journal of Apicultural Research, 49(1), 7-14. 